\author{
Danuta Szajnert \\ Uniwersytet Łódzki \\ e-mail: danka@uni.lodz.pl
}

\title{
Przestrzeń doświadczona, przestrzeń wytworzona - literackie topografie Litzmannstadt Getto (rekonesans). Część pierwsza
}

Tysiące fotografii ludzi i łatwo rozpoznawalnych, bo prawie niezmienionych, miejsc; szczegółowe mapy z polskimi, niemieckimi albo żydowskimi nazwami ulic i placów, dołączane do każdej niemal publikacji na temat łódzkiego getta i dostępne na wielu profesjonalnie zredagowanych stronach internetowych; kilkadziesiąt filmów dokumentalnych; pięć tomów Kroniki Litzmannstadt Getto z zapisami prowadzonymi od stycznia 1941 do końca lipca 1944 roku; monografie opracowane przez historyków; analizy i rekonstrukcje socjologiczne; Litzmannstadt-Getto. Ślady. Przewodnik po przeszłości i Spacerownik: Łódź żydowska oraz wiele innych dokumentów, studiów i informatorów tego rodzaju. Ponadto: wspomnienia z getta łódzkiego, dzienniki, reportaże, pamiętniki, eseje, wiersze, dramaty, opowiadania i powieści oraz... zapamiętane z dzieciństwa, owiane grozą, niezrozumiałe opowieści moich ciotek i ojca, który codziennie, w drodze do pracy, przejeżdżał przez getto „aryjskim" tramwajem - to z jednej strony. Z drugiej: wielokrotne przemierzanie tych zapisanych na mapach ulic; czytanie upamiętniających tablic przytwierdzonych do każdego zachowanego budynku, w którym miały siedzibę ważne gettowe instytucje; śledzenie zacierających się z czasem śladów granic getta, oznaczonych - przed obchodami 60. rocznicy jego likwidacji - białą olejną farbą na bałuckich chodnikach ${ }^{1}$; spoglądanie $\mathrm{z}$ okien naszego instytutowego

\footnotetext{
1 Przed obchodami rocznicy 70. zasięg getta oznaczono stoma granitowymi tablicami wbudowanymi w chodniki.
} 
gabinetu na budynek dawnej wozowni pałacu Biedermannów, do niedawna siedziby biblioteki kulturoznawstwa, w czasie okupacji zaś granicznej, południowej wartowni strzegącego getto Schupo, i z okien mojego mieszkania na Marysinie - na wielki teren cmentarza żydowskiego i drogę, prowadzącą do stacji Radegast, skąd wywożono Żydów do obozów zagłady; wstrząs (Ankersmitowskie doświadczenie przeszłości?), gdy wraz z innymi widzami „spektaklu w przestrzeni miejskiej Szpera' $42^{\prime \prime 2}$ przechodziłam przez ciemne, niskie, śmierdzące bramy i wąskie podwórka-studnie nadal zamieszkanych, obskurnych kamienic, w których podczas okupacji gnieździli się i umierali z głodu i chorób więźniowie „zadekretowanego" ${ }^{3}$ przez Niemców dla Żydów rewiru.

Takie „praktykowanie” miejsc - pozbawione niewinności, zapośredniczone przez teksty, przez nagromadzone informacje innego kalibru niż te, które prefigurują kulturowo przestrzenie odmiennego rodzaju - sprawia, że fragmenty Starego Miasta i tzw. Starych Bałut objawiają swą realność jako przestrzeń postgettowa ${ }^{4}$. Nie jest to, co ważne, przestrzeń „wyczytywana” jedynie z map i „wczytywana” w zapisane na nich, całkowicie odmienione terytorium, jak w przypadku warszawskiego Muranowa czy kowieńskiego

2 Tę, prezentowaną w sierpniu i wrześniu 2012 r., akcję teatralną przygotowali Tomasz Rodowicz i Ruthie Osterman z zespołem teatru Teatru Chorea i artystami z Izraela.

3 Zob. J. Leociak, Topografia i egzystencja, w: tegoż, Doświadczenie graniczne. Studia o dwudziestowiecznych formach reprezentacji, Warszawa 2009, s. 82.

4 Nazwałam ją post-, a nie pogettową, ze względu na potencjał prefiksu post-, ujawniony przede wszystkich w charakterystykach „postpamięci”. Prefiks ów nie tylko uwyraźnia mediację i nieuchronną fragmentaryczność wyobrażeniowej (re)konstrukcji miejsca oraz związane z jego „praktykowaniem” zaangażowanie, ale też akcentuje nieprzekraczalny dystans między tą przestrzenią a rzeczywistym gettem. Jeśli przebywającym $w$ jej kartograficznych ramach „wiedzącym” dane jest doświadczenie współwidzenia, to na ten podwojony obraz składają się współczesny widok jakiegoś miejsca i rozgrywająca się dokładnie w tym miejscu scena z przeszłości, którą próbuje się empatycznie odzyskać - uczynić współobecną, a w konsekwencji: uobecnić nieobecność (zob. tenże, Topografia i egzystencja, s. 119-122). Z tym, że jest to zazwyczaj scena utrwalona na kliszy, jak w przypadku refotografii, wizerunek czy inna reprezentacja, a nie samo to miejsce zapisane w pamięci. Ożywiającą przeszłość technikę refotograficzną w sposób mistrzowski wykorzystał w filmie Litzmannstadt - Bałuty (2013) Tomasz Bermann. Zaproponowane przez niego wizualizacje mogą posłużyć jako proteza wyobraźni, choć pokazują zarazem dobitnie, że - odsłaniające zarówno zmiany, jakie zaszły w miejskim, bałuckim pejzażu, jak i to, co w nim trwałe - zdjęcia z getta łódzkiego precyzyjnie, punktowo nałożone na obrazy zarejestrowane dzisiaj, nie są w stanie sprawić, że gruba warstwa nowej rzeczywistości, która powlekła dawne życie i pustkę po jego zagładzie, zostanie zdarta. Nawiązuję tu do roszczeń skrywających się niekiedy w geo- czy topo-palimpsestowych metaforach - roszczeń niemożliwych do zaspokojenia. W przestrzeni postgettowej nie ma ucieczki od decydującej o jej statusie interferencji obrazów. 
Vilijampola ${ }^{5}$. Jej zabudowa nie została wcześniej doszczętnie wymazana: przez Niemców po likwidacji gett czy decyzją władz polskich po zakończeniu wojny (jak np. w Białymstoku). Do dziś przetrwało w tym rejonie kilkaset kamienic $z$ przedwojnia. $W$ Łodzi wojenne i powojenne wyburzenia objęły przede wszystkim, choć oczywiście nie tylko, drewniane rudery, charakterystyczne dla dzielnicy żydowskiej ${ }^{6}$. Niektóre jej kwartały pozostały nienaruszone lub względnie nienaruszone. Jakby zastygły w czasie - w stanie dawnej ohydy. Tym, co decyduje o radykalnej odmienności tych ocalałych fragmentów przestrzeni getta i przestrzeni po getcie łódzkim, nie są jedynie wtłoczone $\mathrm{w}$ dawną zabudowę bloki, krzykliwe kolory fasad zaniedbanych kamienic, zmienione układy niektórych ulic, samochody, bilbordy i anteny satelitarne, zdewastowany - od lat nieczynny, wyróżniający się na przedwojennych Bałutach wyjątkową okazałością i niezwykle ważny dla więźniów getta jako miejsce traumatyczne - budynek Kasy Chorych przy Łagiewnickiej $34 / 36^{7}$ czy sklep spożywczy w siedzibie gettowego Domu Kultury przy Krawieckiej 3. Rozstrzygają o tej odmienności w głównej mierze nowi mieszkańcy, przysłaniający swoją obecnością nie tylko wszelkie ślady zostawione przez obcych/innych, skazanych w przeszłości na życie w tym miejscu, ale przede wszystkim - pustkę po nich. Pustkę, której często nie są czy nie chcą być świadomi mimo implantów pamięci wszczepianych w tkankę miasta $\mathrm{w}$ ramach zinstytucjonalizowanych praktyk kommemoracyjnych ${ }^{8}$, którym coraz częściej zarzuca się, że miast animować rzeczywistą pamięć, zwalniają od obowiązku pamiętania ${ }^{9}$.

5 Zob. K. Schlögel, Plan getta w Kownie, w: W przestrzeni czas czytamy. O historii cywilizacji i geopoetyce, przeł. I. Drozdowska, Ł. Musiał, Poznań 2009, s. 115-119.

6 W 1941-42 i 44 roku z nakazu władz niemieckich rozebrano też w niektórych rejonach okazałe kamienice trzy- a nawet czteropiętrowe. Zob. Abbruchstelle, rozbiórki, w: Kronika getta łódzkiego/Litzmannstadt Getto, red. J. Baranowski, K. Radziszewska, A. Sitarek i in., Łódź 2009, t. 5 , s. 271.

7 O jego wojennej i powojennej historii opowiada T. Majewski (Litzmannstadt Getto, w: Pamięć Shoah. Kulturowe reprezentacje i praktyki upamiętniania, red. T. Majewski, A. Zeidler-Janiszewska, Łódź 2009, s. 117). Fakt, iż brama z tego „opustoszałego szpitala [...] wraz z kostkami bruku z getta warszawskiego i witrażem ze zniszczonej synagogi z krakowskiego Kazimierza" jest elementem stałej ekspozycji waszyngtońskiego Holocaust Memorial Museum, „stając się rodzajem relikwii, która uosabia w porządku «kosmopolitycznej pamięci» rzeczywistość Ghetto Litzmannstadt", dowodzi, zdaniem autora, znaczącej różnicy między rządzącymi się „odrębnymi prawami" uniwersalną pamięcią Zagłady i jej pamięcią czy raczej niepamięcią lokalną.

8 Zob. W. Skok, Teren, w: Pamięć Shoah, s. 192-194.

9 Zob. E. Rybicka, Miejsca wydrążone z pamięci, w: Geopoetyka. Przestrzeń i miejsce we współczesnych teoriach i praktykach literackich, Kraków 2014, s. 317. 
Z faktu, że literackie, fikcjonalne i niefikcjonalne opowieści z łódzkiego getta, o łódzkim getcie oraz takie, dla których getto to jest pod jakimś względem istotną płaszczyzną odniesienia, czytam $w$ tej właśnie postgettowej przestrzeni, wynikają - jak się okazało - ważkie konsekwencje dotyczące możliwości rozpoznania właściwych tym opowieściom stylów jego topografii. O potrzebie namysłu nad nimi nie zadecydowały one same czy raczej nie one przede wszystkim. Ważniejszą rolę odegrała tu sieć danych dyskursywno-doświadczeniowych: faktów historycznych, obrazów, interpretacji, tropów, wrażeń, wyobrażeń i przeświadczeń, związanych z szeroko lansowaną tezą o wyjątkowości hermetycznie zamkniętego Litzmannstadt Getto na tle innych funkcjonujących w okupowanej Polsce ${ }^{10}$. Ta wyjątkowość czy przynajmniej odmienność przekładała się, w pewnej mierze, na ogólne kategoryzacje o charakterze topologicznym. Byłam przekonana, mając $\mathrm{w}$ najświeższej pamięci poświęcone gettu powieści, że $\mathrm{w}$ interesujących mnie zapisach jego przestrzeni odnajdę literackie odpowiedniki albo ślady tych kategoryzacji. W diariuszowych, felietonowych, reportażowych, wspomnieniowych i powieściowych topografiach getta łódzkiego poszukiwałam deskrypcji czy tropów wskazujących na takie właściwości owej przestrzeni, które można by umownie określić jako endemiczne.

Nie bez związku z miejscem, z którego czytam te różnogatunkowe narracje, pozostaje także kwestia usytuowania ich autorów i - w konsekwencji - ewentualnych różnic w narracyjnym organizowaniu czy wytwarzaniu przestrzeni. Chodzi tu o przestrzeń bezpośrednio doświadczoną, postrzeganą z perspektywy endotycznej, właściwej więźniom getta (endotopia) oraz o przestrzeń modelowaną z perspektywy rodzinnie czy kulturowo zapośredniczonej, zatem egzotycznej (egzotopia) - jedynej nota bene, jaka jest mi dostępna jako odbiorcy opowieści związanych z gettem łódzkim. Dla tej

10 Getto Litzmannastadt było drugim co do wielkości (po warszawskim) i najdłużej istniejącym spośród wszystkich, utworzonych przez okupantów na ziemiach polskich (od lutego 1941 do końca sierpnia 1944 r.). Niemcy nadali miastu nową nazwę po włączeniu go do Rzeszy (region Warthegau). Uczcili w ten sposób gen. Karla von Litzmanna, który dowodził pruskimi wojskami w bitwie o Łódź w czasie I wojny światowej. Niektórzy historycy usiłują podważać tezę o bezwzględnej hermetyczności getta łódzkiego, ale i oni przyznają, że "faktycznie było [ono] najlepiej strzeżonym gettem na ziemiach okupowanych, a do niedozwolonych kontaktów między jego mieszkańcami a Polakami dochodziło rzadko w porównaniu z innymi gettami" (D. Siepracka, Stosunki polsko-żydowskie w Łodzi w czasie okupacji hitlerowskiej. Stan badań i perspektywy badawcze, w: Fenomen getta łódzkiego 1940-1944, red. P. Samuś, W. Puś, Łódź 2006, s. 336). Były to kontakty o charakterze handlowym, w zasadzie podtrzymywane tylko w początkowym okresie funkcjonowania getta. 
pierwszej (endotycznej) istotne wydają się ponadto ramy temporalne. Zapisy z wnętrza getta tworzone tam przez autorów, którzy nie doczekali wyzwolenia, takich jak m.in. Dawid Sierakowiak (Dziennik), Szmul Rozensztajn (Notatnik), Oskar Singer (Przemierzajac szybkim krokiem getto), Józef Zelkowicz (Reportaże), Alice de Buton czy Bernard Heilig (felietony włączone do Kroniki Getta Łódzkiego) mówią nam coś innego niż narracje o getcie spisane po latach przez ocaleńców ${ }^{11}$. Niepodobna utrzymywać, że wiedza nie tylko ta o prawdziwym celu "wysiedleń" - jaką dysponowali po wojnie Sara Zyskind (Skradzione lata i Światło w dolinie łez), Arnold Mostowicz (Żółta gwiazda, czerwony krzyż), Jakub Poznański (Dziennik z łódzkiego getta), Michał Mosze Chęciński (Zegarek mojego ojca), Anatol Chari (Podczłowiek. Wspomnienia członka Sonderkommanda), autorzy powieści - Zenia Larsson, František Kafka, Chava Rosenfarb - czy Jeszajahu Szpigel (jako autor dopiero wtedy powstałych opowiadań) nie oddziałała na obraz getta ukazany $w$ ich utworach. Można wszakże zaryzykować twierdzenie, że za sprawą tejże wiedzy dokonała się post factum przemiana samej gettowej rzeczywistości.

Ze znaczącym zróżnicowaniem mamy również do czynienia $w$ przypadku perspektywy egzotopicznej, właściwej niektórym spośród powiązanych z Litzmannstadt Getto tekstów fikcjonalnych. Tutaj za ważne uznać wypadałoby zarówno źródła informacji o jego przestrzeni (czy są to tylko rozmaite teksty, memoraty, materialne ślady przechowywane w miejscach pamięci kulturowej - muzeach i archiwach - czy również "badania terenowe"), jak i stopień respektu dla tych źródeł, decydujący m.in. o proporcjach między dokumentaryzmem czy quasi-dokumentaryzmem a inwestycją wyobraźni.

Interesuje mnie możliwość odpowiedzi na pytanie o to, co przede wszystkim decyduje o sposobach modelowania tej przestrzeni: endo- czy egzotopia w obu przywołanych wariantach, wskazujących na źródła i zakres autorskiej wiedzy; kategoryzacje właściwe jednostkowej wrażliwości topograficznej i wyobraźni czy względy architekstualne (reguły stylistyczno-gatunkowe, konwencje dyskursywno-rodzajowe, kody semiotyczno-kulturowe ${ }^{12}$ )?

Zważywszy ponadto na fakt, że nazwa egzotopia to, według translatologicznej propozycji Tzvetana Todorowa, odpowiednik Bachtinowskiej wnienachodimosti (a więc właśnie niewspółobecności, postronności, stanowiska zewnętrznego, pozycji spoza), nie sposób pominąć uwikłania zagadnień ewoko-

11 Jakub Poznański i Jeszajahu Szpigel pisali co prawda w getcie, ale mieli później możliwość redakcji swoich tekstów.

12 Wg wykładni tego Genette'owskiego pojęcia zaproponowanej przez R. Nycza (Poetyka intertekstualna: tradycje i perspektywy, w: Kulturowa teoria literatury. Główne pojęcia i problemy, red. M. P. Markowski, R. Nycz, Kraków 2006, s. 161). 
wanych przez to pojęcie w problematykę aksjologiczną. Dla Bachtina wnienachodimost' to jedna z kluczowych wartości - zarówno wtedy, gdy ujmuje ją jako warunek estetyczno-antropologicznego powodzenia w konstruowaniu bohatera, jak i wtedy, gdy przedstawia jako faktor stanowiący o twórczym oglądzie i rozumieniu cudzej kultury, która ujawnia się dopiero w optyce kultury odmiennej - w przestrzennym, czasowym, kulturowym oddaleniu. Istotne zatem wydaje się rozważenie, czy perspektywa egzotopiczna, siłą rzeczy stowarzyszona z pracą pamięci zmediatyzowanej, rzeczywiście odsłania jakieś nowe, wcześniej nierozpoznane czy przemilczane rejony zamkniętego świata Litzmannstadt Getto.

Produktem takiej pamięci są niewątpliwie następujące powieści (porządkuję je według czasu, w jakim zostały opublikowane): Król żydowski (King of the Jews, 1979) Leslie Epsteina - Żyda amerykańskiego, o którym wiadomo, że nigdy nie był w Łodzi; Fabryka muchołapek (2008) Andrzeja Barta, świetnie znającego to miasto i jego postgettową przestrzeń; Biedni ludzie z miasta Łodzi (De fattiga i Łódź, 2009) Steve'a Sem-Sandberga - Szweda, wielokrotnie podkreślającego, jak ważną rolę w opracowywaniu jego ogromnego, kilkusetstronicowego dzieła odegrały wizyty w Łodzi, poświęcone nie tylko studiom archiwalnym, ale też spacerom po „zaginionej dzielnicy” ${ }^{13}$ żydowskiej, podczas których miał słyszeć "głosy getta", czy wreszcie rzecz adresowana do dziecięcego czytelnika, czyli Bezsenność Jutki (2012) autorstwa łodzianki, Doroty Combrzyńskiej-Nogali oraz Naród zatracenia (2014), powieść graficzna łodzianina Macieja Świerkockiego (tekst) i Mariusza Sołtysika (rysunek). Za postpamięciową, apokryficzną powieść wystylizowaną na dokument osobisty można też uznać Byłam sekretarka Rumkowskiego. Dzienniki Etki Daum (2008) - napisane „od nowa” przez Elżbietę Cherezińską, ponoć na podstawie autentycznych bezładnych wspomnień Daum, pracownicy Centralnego Sekretariatu Getta.

Znacznie bardziej problematyczne jest czasowo-przestrzenne usytuowanie autora Jakuba Łgarza (Jakob der Lügner, 1969). Mimo iż getto przedstawione $\mathrm{w}$ tej powieści nie ma niemal żadnych endemicznych właściwości pozwalających na jego identyfikację, wiedzę, iż ów autor, czyli Jurek Becker, był ocaleńcem, który tu właśnie - w getcie łódzkim - przebywał jako małe dziecko, traktuje się jako poszlakę biograficzną, pozwalającą łączyć opowiedzianą przez niego fikcyjną historię $\mathrm{z}$ autentycznymi, lokalnymi wydarzeniami, tyczącymi kolportowania zakazanych wiadomości radiowych i gazetowych. Problem z usytuowaniem polega na tym, że Becker deklarował,

13 Zob. P. Spodenkiewicz, Zaginiona dzielnica. Łódź żydowska - ludzie i miejsca, Łódź 1998. 
iż ze swojego dzieciństwa nie pamięta nic oprócz wszechogarniającej szarości, którą zasnuł ulice i domy getta wytworzonego w powieści. Źródła danych, m.in. topograficznych (choć o nie specjalnie się nie troszczył), które wykorzystał w pracy nad nią, nie różnią się zasadniczo pod względem statusu od tych, na których bazowali autorzy egzotopiczni.

Kwestie te są istotne, ponieważ Bachtinowskie estetyczno-poznawcze uprzywilejowanie egzotopii pozostaje w sprzeczności ze stanowiskiem zajmowanym przez ortodoksyjnych strażników pamięci Holokaustu. Wzajemne uwikłanie powieściowości, postpamięci i innych form pamięci zapośredniczonej oraz niewspółobecności stanowi - jak można zaobserwować - zadziwiająco trwałe podłoże zarzutów stawianych tekstom będących jego efektem. Zarzutów, które często świadczą o (powiedzmy) naiwnym pojmowaniu etyki reprezentacji. Nadal słyszy się pytania typu: jaki sens ma fikcjonalizacja Zagłady, po co pisać powieści o Holokauście, a zatem i o łódzkim getcie, skoro dysponujemy $\mathrm{z}$ jednej strony $\mathrm{z}$ założenia bardziej wiarygodną, zatem wartościową literaturą świadectwa, z drugiej - opracowaniami naukowymi i komentowanym pełnym wydaniem Kroniki Litzmanstadt Getto? Znacznie łagodniej traktowane są przez ortodoksów fabuły autorstwa ocalałych: wstrząsające opowiadania Jeszajahu Szpigla - niektóre z nich napisał podczas pobytu w getcie - pierwsza o nim powieść, czyli Cienie przy drewnianym moście (Skuggorna vid träbron, 1960) Zeni Larsson, Okrutne lata (Krutá léta, 1962) Františka Kafki, który trafił do Łodzi w 1941 r., w II transporcie praskim, czy Drzewo życia (Der boim fun lebn, 1972), trzytomowa powieść autobiograficzna więźniarki tego getta, Chavy Rosenfarb, uważanej za najwybitniejszą współczesną pisarkę jidysz. Rękojmię wartości tych fabuł stanowić ma osobiste doświadczenie, fakt, iż zostały wydobyte $\mathrm{z}$ własnej pamięci, wysnute $\mathrm{z}$ doświadczonej, a nie wytworzonej przestrzeni. Jednakże zapomina się o tym, że decyzje o wyborze gatunkowej formy powieści są często tłumaczone przez twórców właśnie ograniczeniami jednostkowego doświadczenia, pamięci, prawdy, a nie tylko koniecznością autoterapeutycznego podporządkowania zapamiętanego prawom formy.

Na uwagę zasługuje też fakt, że to właśnie w pisanych z perspektywy endo- lub egzotopicznej powieściach i innych prototypowych formach literackich, związanych tematycznie z Litzmannstadt Getto, odnaleźć można próby jego topografii, rozumianych jako opisy wyglądu terenu, miejsc, przestrzeni. W diariuszowych, pamiętnikarskich czy nawet reportażowych wypowiedziach o tymże getcie przestrzeń jest wszechobecna, ale takich topografii - angażujących zmysły, sprzyjających wizualizacjom, wyobraźniowemu jej odtworzeniu $-\mathrm{w}$ zasadzie nie ma lub prawie nie ma. Ponadto 
getta $w$ nich ukazanego niemal $w$ ogóle nie słychać; jest nieme ${ }^{14} \mathrm{i}$, co może wydawać się dziwne, pozbawione zapachu. To, że wcześniej tego nie zauważyłam jest, powtórzę, konsekwencją faktu, iż czytając te teksty w postgettowej przestrzeni dyskursywno-doświadczeniowej bezwiednie, tam gdzie to było możliwe, wypełniałam brakujące fragmenty minionej rzeczywistości obrazami getta wypożyczonymi z tej przestrzeni.

\section{Niefikcje (endotopia)}

Niemal żadnych miejskich pejzaży, ani wzrokowych, ani zapachowych czy dźwiękowych nie ma też w Kronice..., najważniejszym tekście z łódzkiego getta. Co prawda, po wprowadzeniu (w 1943 r.) do Biuletynu Kroniki Codziennej rubryki zatytułowanej Małe zwierciadło getta pojawiają się w tym teście jakieś zalążki obrazów, ale mogą one co najwyżej odegrać rolę impulsu dla imaginatywnych przedstawień przestrzeni. Pobudza je zapewne już pierwsze zdanie felietonu Przywilej kotów, z 15 stycznia 1944 r.: "Jedną z osobliwości getta Litzmannstadt jest brak jakichkolwiek zwierząt domowych"15. Trudno byłoby dopatrzyć się takiego impulsu w ironicznym początku Nocnego życia $w$ getcie, z lutego tego samego roku. „Obok Ameryki to getto Litzmannstadt jest krajem nieograniczonych możliwości. To, co jeszcze wczoraj było surowo zabronione, nazajutrz jest obowiązującym prawem" - oznajmia autorka tych tekstów, przybyła z Berlina Alice de Buton ${ }^{16}$. Potem jednak szkicuje obraz ulic i mieszkań getta całkowicie wyludnionych za dnia, od zmroku natomiast do późnej nocy zapełnionych wymęczonymi ludźmi, wędrującymi do punktów odbioru węgla, racji żywnościowych, „sklepów rozdzielczych" czy aptek - efekt nowego, absurdalnego, lekceważącego zmianowy rytm pracy zarządzenia władz, które objęło również zakaz przebywania w mieszkaniach

\footnotetext{
14 Charakterystyczny dźwiękowy obraz z Litzmannstadt Getto przywołał, pracujący tam jako lekarz, Arnold Mostowicz w filmie Fotoamator Dariusza Jabłońskiego (1998). Wracając z nocnego dyżuru, usłyszał jednostajnie narastający, rytmiczny huk. Okazało się, że jest to odgłos uderzających o uliczny bruk tysięcy drewnianych trepów, które nosili więźniowie getta; zbliżała się godzina rozpoczęcia pierwszej zmiany w „resortach”, czyli zakładach produkcyjnych. $\mathrm{O}$ „wypłakiwanych" przez dzieci „sacharynowych melodiach”, czyli o nawoływaniach małych ulicznych sprzedawców sacharyny i cukierków toffi, wspomina w jednym ze swoich „reportaży" O. Singer. Zob. Tegoż, Przemierzając szybkim krokiem getto. Reportaże i eseje z getta łódzkiego, przeł. K. Radziszewska, Łódź 2002, s. 70.

15 Kronika Getta Łódzkiego, t. 4, s. 36. To, co „zabronione” dotyczy rygorów związanych z godziną policyjną.

16 Tamże, s. 150.
} 
od godziny ósmej do siedemnastej. Prezesa przeraziły bowiem opinie wizytujących getto niemieckich komisji o tłumie nieustannie przelewającym się ulicami w tych godzinach, w których wszyscy przecież mają obowiązek pracować.

W piątym tomie polskiego wydania Kroniki... redaktorzy zamieścili opracowania i kilka bardziej rozbudowanych niż już przywołane felietonów, które najprawdopodobniej nie były włączone do Biuletynu..., ale niewątpliwie stanowiły materiały zredagowane - tak jak on - $\mathrm{w}$ ramach działalności utworzonego w listopadzie 1940 r. Wydziału Archiwum. To właśnie wśród tych dokumentów, tworzonych z myślą o przyszłych badaczach, znalazłam i takie, z których można się dowiedzieć, jak wyglądało getto czy raczej jak objawiło się zesłanym do niego Żydom praskim, wiedeńskim, berlińskim. W felietonie powstałym w maju 1942 r. deportowany z Pragi Bernard Heilig dobitnie określił ich naturę: „Niedostatecznie ukrwiony mózg [...] z odrazą odbiera wrażenia, z odrazą je przechowuje i z odrazą bez zmiany przekazuje". Odraza towarzysząca przesiedleńcom $\mathrm{w}$ drodze od stacji Radegast, która znajdowała się poza granicami getta, do miejsca zakwaterowania tylko na moment ustąpiła innemu doznaniu.

Droga wydawała się nam niesłychanie długa. Prowadziła ona z początku przez wolne pole, zmieniła się potem $\mathrm{w}$ okolicę o małych, przeważnie nowych zabudowaniach, w końcu wcisnęliśmy się między rzędy domów. Ale cóż to były za domy! Teraz zdaliśmy sobie sprawę: jesteśmy w getcie. [...] Niesamowite wrażenie wywarł na nas ogromny, czerwony kościół i krucyfiks pośrodku getta. Stanęliśmy przed wielkim budynkiem z wielką bramą. Byliśmy u celu: Hausedenstrasse $37^{17}$.

W innym felietonie z cyklu Pierwsze siedem miesięcy $w$ getcie Litzmannstadt, opatrzonym podtytułem Mieszkańcy baraków dla deportowanych, Heilig najpierw przedstawia kilkoro spośród nich - świetnie wykształconych przemysłowców, prawników, inżynierów i ich rodziny - potem miejsce, do którego trafili, czyli Bałuty „,[w] czasach normalnych zamieszkałe przez największą biedotę, przez proletariat i po największej części przez lękającą się światła nędzę". Następnie pokazuje, jak zostało ono - w czasach nienormalnych przemienione $\mathrm{w}$ rozległe więzienie i zaznacza punkty najbardziej charakterystyczne dla tak wydzielonej przestrzeni.

17 B. Heilig, Felieton „Pierwsze siedem miesięcy w getcie Litzmannstadt. Przelotne wrażenia $i$ obrazy", w: Kronika, t. 5, s. 208. Rzeczywista niemiecka nazwa ulicy, przy której zakwaterowano II transport praski, to Hanseatenstrasse, czyli przed- i powojenna Łagiewnicka. 
Na krańcach, gdzie do miasta prowadziły linie tramwajowe, otoczono ten kwartał żydowski drutami, rusztowaniami wyższymi niż postać ludzka. Niemieccy żołnierze, przeważnie policja (schupo) sprawowali stałą, regularną, ostrą służbę wartowniczą, rozmieszczeni na określonych posterunkach wzdłuż drutów i na krzyżowaniu się dróg. Trzy wysokie mosty drewniane przeszywały ponad jadącymi pod nimi tramwajami ulice, które z terenu getta wyłączały odcinki dzielnic aryjskich. Przekroczenie ich było Żydom surowo wzbronione. Frekwencja przechodniów na mostach, zwłaszcza na tym wielkim, przy czerwonym kościele wywoływała lęk, szczególnie o pewnych godzinach.

Heilig wyróżnia też Baluter Ring - siedzibę

przełożonego Starszeństwa Żydów, jego sztabu i gettowych władz niemieckich. [...] Ludność getta - pisał - wymawiała nazwę Bałucki Rynek z namaszczeniem. Tu była właściwa rezydencja, „dzielnica rządu”, zamek warowny, oddzielone drutami od właściwego getta, jakoby wyjęte spod jego zasięgu. [...] Pozostały teren za drutem kolczastym, to teren beznadziejnej nędzy, głodu, smutku i zwątpienia ${ }^{18}$.

Jeśli się zważy na fakt, że ta rządowa rezydencja to kilka niedbale skleconych drewnianych baraków, wyraźniej objawią się rzeczywiste źródła kontrastu Bałuckiego Rynku i pozostałych części getta, podkreślanego przez tych przede wszystkim, którzy nie mieli do niego dostępu.

Nadmieniając zaledwie o bardziej okazałych czy nawet ładnych budynkach z balkonami, stojących przy głównych ulicach żydowskiego rewiru, szczególną uwagę poświęca Heilig przeważającej na jego obszarze nędznej zabudowie drewnianej: parterowym, jedno- a nawet dwupiętrowym, szarym lub zielonym, zapadającym się domkom i przedzielającym je rumowiskom. Nie zapomina też o oddzielnych budach, w których „znajdowały się [...] nieuniknione ustępy" ${ }^{\prime 1}$. Wszak stanowiły one ważny rys getta; tylko niewielka część Bałut była skanalizowana. „Fekaliści” - nędzarze zaprzężeni do wozu z fekaliami - to stały, uwieczniony na wielu fotografiach element rejestrowanego przez autorów świadectw gettowego krajobrazu.

Na podstawie tychże świadectw stosunkowo niewiele można powiedzieć o roli, jaką w doświadczeniu topografii getta łódzkiego odegrały - rozdzierające jego przestrzeń na trzy sektory (getto A, B i C) - wspomniane przez Heiliga eksterytorialne, tranzytowe ulice. Jeździły po nich, jak w getcie warszawskim czy krakowskim, aryjskie tramwaje i samochody. Większe emocje, jak się wydaje, budziła linia tramwajowa, zbudowana przez Żydów dla nich

18 Tamże, s. 211. 
samych ${ }^{20} \mathrm{i}$ - przede wszystkim - rozpięte nad tymi ulicami mosty ${ }^{21}$. Tramwaje dla aryjczyków uczyniła jednak bohaterami swego szkicu inna współautorka Biuletynu Kroniki Codziennej, deportowana z Wiednia Alice de Buton.

Tramwaj nr 3 - kierunek Aleksandrów, tramwaj 40 - Ozorków, 41 - Zgierz, nr 50, 1, 5, 7, tramwaj L. Przesuwają się przed naszymi oczami podwójne, potrójne wozy: tramwaj z Łodzi.

Łódź! Zamknięta, niedostępna dla nas, oznacza „świat". [...]

Na tabliczkach napisy: "tylko dla Niemców", „tylko dla Polaków”; nie widać żadnej, która by i „dla Żydów” zezwolenia udzieliła.

Niedziela. W tramwaju tłumy. Dobrze ubrani, wolni, pogodni ludzie wyruszają $\mathrm{z}$ wycieczką $\mathrm{w}$ okolice, stoją na pomostach lub siedzą za niebieskimi oknami ${ }^{22}$.

Ten zapis, w dodatku nie w pełni czytelny, jak informują redaktorzy polskiego wydania Kroniki, to jedna z zaledwie kilku nieliterackich (w prototypowym rozumieniu) prób konfrontacji „tej” i „tamtej” strony getta, podjęta przez osobę w nim uwięzioną. Niepodobna jednak nie zauważyć, że "świat” - reprezentowany metonimicznie przez pasażerów tramwaju - jest tu nie tylko odgrodzony od patrzącej zamalowaną na niebiesko szybą (i, wypada dodać, płotem z desek i drutu kolczastego, oddzielającym eksterytorialną jezdnię od gettowych chodników). Świat ten bowiem jest dostępny z takiego oddalenia wtedy jedynie, gdy przejeżdża przez getto. Nie ma innego sposobu, by zbliżyć się do rzeczywistości extra muros. „Snuje się marzenia o wolności, o pokoju. Smutne. Wolność ta sięga tylko do płotu. Brama getta zawarta. [...] Myśli są wolne od cła... Jedynie one mają prawo getto opuścić" - dopowiada de Buton w innym felietonie ${ }^{23}$.

Wedle mojej wiedzy nie ma żadnych, tworzonych na bieżąco, zapisów o getcie widzianym zza tramwajowej szyby. Dopiero w 2012 r. ukazała się książeczka autorstwa Antoniego Kerima Tramwajem przez Łódzkie Getto, czyli wspomnienia z czasów II wojny światowej. W tej powstałej w roku 2010 krótkiej relacji z okupacyjnego bałuckiego dzieciństwa temu, co zostało wy-

20 Była to linia tramwajowa łącząca Rynek Bałucki ze stacją Radegast, ułatwiająca wycieńczonym mieszkańcom getta docieranie do resortów położonych na Marysinie. Służyła jednak przede wszystkim do transportu żywności i innych produktów.

21 Ruch kołowy między tymi sektorami - dotyczyło to również wozów zaprzężonych w ludzi - zapewniały bramy. Otwierano je tylko wtedy, gdy jezdnie Zgierskiej i Limanowskiego były puste. Pieszych także przepuszczano czasem przez te bramy; decydował o tym kaprys niemieckich wartowników.

22 A. de Buton, Felieton „Rzut oka przez okno... albo ostatnie światełko niebieskie”, w: Kronika, t. 5, s. 204.

23 Drobny przekrój getta, w: Kronika, t. 5, s. 203. 
różnione tytułem, autor (o którym nie sposób znaleźć jakiejkolwiek informacji) poświęcił jednak bardzo mało uwagi. Mieszkał niedaleko zachodniej granicy getta - najpierw na Limanowskiego 102, potem na Wrześnieńskiej 115; odnotował jego powstanie, poinformował (z błędami) o obszarze, jaki dla niego wytyczono. W marcu 1943 r. jako dwunastolatek musiał podjąć pracę.

Do pracy - pisał - jeździłem tramwajem przez Getto. Tramwaj był zamykany na klucz i pilnowany przez konduktora, żeby nie dopuszczać do rzucania czegokolwiek za mury Getta. Ludzie chodzili tam chwiejnym krokiem i byli bardzo chudzi. Na parapetach zamiast kwiatów hodowali włoszczyznę. Na rękawach i na piersiach odzieży mieli naszyte gwiazdy Dawida. Tramwaj przejeżdżał do końca ulicy Limanowskiego, przy bałuckim Rynku skręcał w ulicę Zgierską i zatrzymywał się dopiero na ulicy Nowomiejskiej przy placu Wolności. Getto kończyło się przy ulicy Północnej ${ }^{24}$.

Z tych codziennych podróży przez łódzkie getto autor zapamiętał trzy obrazy z roku 1944. W centrum pierwszego umieścił dawnego sąsiada, ulubieńca wszystkich okolicznych dzieci, czule przez nie żegnanego, gdy musiał opuścić dawne mieszkanie. Maks Haskel, widziany po raz ostatni, był tak wycieńczony, że "trzymał się rozłożonymi rękoma framugi okna, żeby nie upaść". Niegdyś elegancki i postawny, teraz obdarty, zgarbiony, "[w]yglądał jak ukrzyżowany, konający Chrystus". Znających układ bałuckich ulic i historię Litzmannstadt Getto zdziwi zapewne kompozycja tego obrazu, ujrzanego jakoby podczas przejazdu eksterytorialną ulicą Limanowskiego. We wspomnieniu scena zyskała drugi plan: „Na bałuckim Rynku stała szubienica, na której wisieli ci, którzy pomagali Żydom. Do rąk mieli przywiązaną tablicę z napisem "polscy bandyci». Na ich tle widać było ukrzyżowanego Maksa H. Skóra mi ścierpła" ${ }^{25}$. Drugi obraz, ukazany z wyjątkową akrybią, miał chyba dotyczyć epizodu z akcji likwidacyjnej - przedstawiał Niemców zmuszających małe dzieci do skoku z pierwszego piętra na odkryte platformy ustawionych pod balkonami samochodów. Te, które się opierały, były siłą wyrzucane przez żydowską policję. Ze szczególną uwagą opisana jest tu empatyczna reakcja polskich świadków tej sceny - zwłaszcza samego piszącego i kobiet, które zemdlały i wymagały długiego cucenia. Widok bliskiego śmierci Maksa Haskela również - jak się dowiadujemy - pobudził do płaczu nie tylko autora wspomnień, ale i innych pasażerów tramwaju. Ostatni

\footnotetext{
24 A. Kerim, Tramwajem przez Łódzkie Getto, czyli wspomnienia z czasów II wojny światowej, Warszawa 2012, s. 36-37 [pisownia oryginalna].

25 Tamże, s. 37 [pisownia jw.]
} 
zarejestrowany przezeń obraz z getta łódzkiego ma charakter dźwiękowy. Jadąc tramwajem, autor usłyszał zza drutów „krzyki i płacz bitych ludzi. To policja żydowska pastwiła się nad swoimi rodakami"26. Źródła informacji o prześladowcach nie ujawnił, choć nic nie wskazuje na to, by był naocznym świadkiem tej sceny przemocy.

Porównując okupacyjne i powojenne relacje Polaków przejeżdżających tramwajem przez getto warszawskie, Jacek Leociak zauważył, że

te powstałe post factum mają zupełnie inny status. Są przepuszczone przez filtr pamięci, w której osadza się to, co najbardziej dojmujące, albo też to, co najbardziej stereotypowe i schematyczne, należące już do pamięci zbiorowej. W powojennych świadectwach ocena dominuje nad opisem ${ }^{27}$.

Tym natomiast, co najbardziej uderzało w świadectwach tworzonych na gorąco, było zarejestrowane w nich poczucie przeraźliwej obcości, dziwności, egzotyki miejsca niegdyś dobrze znanego. Świat widziany zza szyby aryjskich tramwajów objawił się ich autorom jako radykalnie różny nie tylko od tego z drugiej strony murów, ale też od wszystkiego, z czym wcześniej dane im było się zetknąć.

Antoni Kerim niczego takiego nie rejestruje. Obsadzając siebie $\mathrm{w}$ roli świadka, na pozór odnotowuje to, co nim najbardziej wstrząsnęło - $\mathrm{w}$ istocie świadczy za czymś, czego we wskazanej przezeń przestrzeni nie było i w ten sposób powiela (nie wiadomo, czy świadomie) propagandowe klisze. Mniejsza już o to, że dwukrotnie przypomina o niechlubnych działaniach żydowskiej policji czy o powszechnie okazywanym współczuciu dla ofiar getta; najwięcej wątpliwości budzi bowiem scena mająca świadczyć nie tylko o wspólnocie żydowskiego i polskiego losu, ale przede wszystkim o okrutnej karze za czynne okazywanie tego współczucia. Problem polega jednak na tym, że - po pierwsze - w Litzmannstadt Getto wszystkie egzekucje przez powieszenie odbyły się nie w 1944, lecz w 1942 roku $^{28}$. Po wtóre, ich miejscem nie był Rynek Bałucki, tylko niewidoczny z okien tramwaju, położony między ulicą Bazarną i Lutomierską, plac zwanym Bazarowym albo Bazarnym (Bazarplatz), czyli według nomenklatury przedwojennej, Plac Tanfaniego ${ }^{29}$ (dziś Piastowski). Po trzecie i najważniejsze - ofiarami tych egzekucji byli Żydzi; w Łodzi żaden Polak nie został stracony za pomoc dla nich.

\footnotetext{
26 Tamże, s. 40.

27 J. Leociak, Topografia i egzystencja, s. 116.

28 Zob. Kronika Getta Łódzkiego, t. 2, s. 43, 397, 503.

29 Od nazwiska fundatora wybudowanych tam w końcu XIX w. hal handlowych.
} 
„Aby nie patrzeć na cierpiących w getcie, pomyślałem, że mógłbym jeździć do pracy na rowerze" 30 - napisał Kerim po prezentacji rzekomo zapamiętanych obrazów. Wydaje się jednak, że czyniąc niewielki, wystawiony na „aryjskie" spojrzenie fragment przestrzeni getta łódzkiego sceną wydarzeń, których zobaczyć nie mógł, albo nie dostrzegł w tej przestrzeni nic wystarczająco patetycznego, albo - jak inni - odwrócił wzrok od rzeczywistego cierpienia i absolutnej samotności ginących, zanim, przesiadłszy się na rower, zmienił trasę przejazdu do pracy.

„Ludzka zdolność do zapominania o tym, o czym nie chce się wiedzieć, odwracania wzroku od tego, co leży przed oczyma" ${ }^{31}$ przysłużyła się też Niemcom. Volksdeutsche, miejscowi i przesiedleni do Łodzi ze Wschodu i Południa ${ }^{32}$ oraz Reichdeutsche, m.in. tacy, którzy przybyli tu po alianckich nalotach na miasta III Rzeszy, skuszeni obietnicą poprawy warunków życia, nie tylko - jak wspominają ci spośród nich, którzy mieli wtedy po kilka czy kilkanaście lat - nigdy nie rozmawiali o tym, co dzieje się w północnej stronie miasta, ale też zabraniali dzieciom wspominać komukolwiek o tym, co zobaczyły, przejeżdżając przez getto ${ }^{33}$.

Zarówno Polacy, jak i Niemcy pytani o to, co zapamiętali z łódzkiego Wohngebiet der Juden, przywołują przede wszystkim rozpięte nad Zgierską i Limanowskiego wysokie, drewniane mosty dla pieszych. Jako że ulica Zgierska wznosiła się nieco ku górze, patrząc z „aryjskiej” strony można

30 A. Kerim, Tramwajem przez Łódzkie Getto, s. 41.

31 W. G. Sebald, Wojna powietrzna i literatura, przeł. M. Łukasiewicz, Warszawa 2012, s. 52. $\mathrm{W}$ powojennych relacjach ustnych zdarzają się jednak sugestie, że byli i tacy, którzy mogli z upodobaniem przyglądać się gettu. J. Sobczyński (Wywiad przeprowadzony przez M. Kołpakowską. Projekt "Ślady”, Łódź 2004, w: Europa według Auschwitz. Litzmannstadt Ghetto, red. M. Miller, Oświęcim 2009, s. 218) np. opowiadał, że przejazd przez nie tramwajem kosztował tylko 5 fenigów, podczas gdy za zwykły normalny bilet trzeba było zapłacić 20 fenigów. „Można było wykupić też bilet za 50 fenigów, czyli dziesięcioprzejazdowy. No więc niektórzy to tak traktowali: »Proszę przyjedźcie, to zobaczycie Żydów po drodze«. T. Gierłowski (Wywiad przeprowadzony przez M. Gierłowską, tamże) wspominał, że co prawda z powodu zamalowanych szyb „[n]ie można było dokładnie przyjrzeć się temu, co dzieje się w getcie, ale ,"[1]udzie zeskrobywali farbę z okien. Byli ciekawi”. Te wyglądające przez ",szyby tramwaju [...] ciekawe twarze chrześcijan" widział z gettowych ulic A. Cytryn (Obrazki z życia Litzmannstadt Getto, w: Wżart się we mnie ból... Próby literackie Abrama Cytryna, red. D. Leśnikowski, K. Radziszewska, E. Wiatr, Łódź 2009, s. 107).

32 W miejsce Żydów i wysiedlonych do Generalnej Guberni Polaków (ok. 40000) sprowadzono do Łodzi, w ramach akcji Heim ins Reich, ludność niemiecką z Litwy, Łotwy, Estonii, ZSRR i Rumunii. Pod koniec wojny w mieście żyło 140000 Niemców - prawie dwukrotnie więcej niż w roku 1939. 25\% ludności miasta stanowili Volksdeutsche.

33 Zob. projekt „Koniec Lodzermenscha?” - rozmowy ze świadkami historii, będącymi byłymi i obecnymi obywatelami Łodzi, http://www.lodzermenschen.net/pl [dostęp: 14.03.2014] oraz J.-J. Ventzki, Cień ojca, przeł. M. Barcz, Warszawa 2012, s. 189-191, 256. 
było, zwłaszcza w pogodne dni, dojrzeć bez konieczności wsiadania do tranzytowego tramwaju dwa spośród tych mostów, łączące zachodnią i wschodnią stronę getta: pierwszy przy ulicy Podrzecznej i Starym Rynku, kolejny (ten był najczęściej fotografowany) przy Lutomierskiej.

Przejście przez ów most stanowiło niemały wysiłek, dla jednych fizyczny, dla drugich psychiczny. Ludziom starszym, schorowanym, osłabionym - strome stopnie mostu sprawiały, szczególnie zimą, dużą trudność. Stojąc zaś na moście i patrząc w kierunku południowym, miało się perspektywę na część Zgierskiej, Nowomiejskiej i Piotrkowskiej, które prostą linią przecinały miasto. W perspektywie tej jedni starali się odszukać elementy życia wielkomiejskiego, niczym ślady życia $\mathrm{w}$ kosmosie, a inni $\mathrm{z}$ nostalgią $\mathrm{w}$ rysujących się $\mathrm{z}$ dala konturach przedmieścia odnajdowali zaprzeszłą normalność, normalność często szarą, pustą, nijaką, w której żyli rzadko kiedy szczęśliwi, nie przewidując, jak różne oblicze może mieć szczęście... Potem schodziło się w dół i po prawej stronie miało się kościół Najświętszej Marii Panny, którego patronkę Niemcy wysiedlili jak zwykłą Żydówkę ze Wschodniej ${ }^{34}$.

Wydaje się, że to raczej na ten pierwszy most zabierała swoją pięcioletnią krewną kilkunastoletnia wtedy Sara Zyskind, bo kierowała wzrok nie ku położonym na północy przedmieściom, ale w stronę centrum Łodzi. Na moście - czytamy w jej spisanych po latach wspomnieniach - opowiadała dziewczynce "o Placu Wolności znajdującym się u wylotu ulicy Zgierskiej i o pomniku polskiego bohatera, który Niemcy wysadzili w powietrze" i o tym, że niedaleko stał dom, w którym była "tak szczęśliwa” "35. W przeciwieństwie do niej mała Rysia, która - trzeba dodać - w getcie nie głodowała, jako że jej matka miała prawo do zwiększonych racji żywnościowych, i tu „była szczęśliwym dzieckiem, ponieważ nie znała świata innego od tego, w którym żyła. To ja zaczęłam otwierać jej oczy, opowiadając o świecie poza murem i drutem kolczastym" - pisze Zyskind. Te opowieści o przestrzeni realnej

\footnotetext{
34 A. Mostowicz, Żółta gwiazda i czerwony krzyż, Warszawa 1988, s. 24. Nie tylko więźniowie getta, ale też pamiętający te mosty Niemcy i Polacy podkreślali, że zawsze było na nich pełno ludzi. Takie oto wspomnienie przywołała po wielu latach J. Bieńczakowa (Wywiad przeprowadzony przez Z. Kraszewską-Kelcz, Projekt "Ślady”, Łódź 2004, w: Europa wedtug Auschwitz, s. 220), która była wówczas małą dziewczynką: „Kiedyś czekałyśmy z mamą na tramwaj do Zgierza. Stałyśmy na Nowomiejskiej. Patrzyłam na most na Zgierskiej, jak poruszał się po nim tłum... mrówek".

35 S. Zyskind, Skradzione lata, przeł. A. Wiśniewska-Walczyk, Warszawa 1991, s. 144. Mostowicz to nawiasem mówiąc jeden z nielicznych autorów, który - inaczej niż m.in. Zyskind właśnie - unika melodramatycznych efektów, polegających na wzmacnianiu kontrastu między „zaprzeszłą normalnością” i życiem w getcie, przesłodzonymi obrazami przedwojennego szczęścia rodzinnego i dobrobytu.
} 
okazały się dla dziewczynki znacznie bardziej czarodziejskie i intrygujące niż "tradycyjne bajki" $36 \mathrm{z}$ ich wyimaginowanymi topografiami.

$\mathrm{Z}$ tego samego mostu spojrzała kiedyś ku rozświetlonemu ostatnimi promieniami słońca Placowi Wolności Sara Selver-Urbach:

Pod mostem była ulica Zgierska, która nie należała do granic getta. Tam w dole był inny rodzaj życia i ci ludzie, tacy wolni, mimo wojny. Prymitywny, drewniany most został wzniesiony po to, żebyśmy my, Żydzi, nie zanieczyszczali swą obecnością aryjskiej części miasta. [...] Pomyślałam, że i słońce też się od nas odwróciło. Bo najpierw zawsze zmierzchało w getcie. A dopiero później w mieście, gdy ciemność już panowała nad naszymi ulicami ${ }^{37}$.

Niewielkie bałuckie fragmenty niedostępnego Żydom świata można było podejrzeć tylko z pewnego oddalenia - zbliżanie się do drutów groziło śmiercią. $\mathrm{W}$ domach położonych przy zachodniej granicy $\mathrm{z}$ ",aryjską" częścią miasta taką możliwość dawały okna. W Litzmannstadt Żydzi w zasadzie nie podejmowali prób wydostania się z przydzielonego im rewiru i przetrwania w ukryciu poza nim. Wąski wycinek lepszej, jasnej, śródmiejskiej, zarezerwowanej przede wszystkim dla Niemców strony miasta był osiągalny jedynie dla wzroku spoglądających z mostu. Żeby Żydów od tej strony całkowicie odgrodzić, w lutym 1941 r. Niemcy nakazali wyburzenie dużego obszaru okazałej, murowanej zabudowy staromiejskiej wzdłuż południowej granicy getta ${ }^{38}$. Powstały po uprzątnięciu ruin prawie dwustumetrowy pas gołej ziemi dodatkowo je stygmatyzował, wydzielał

$\mathrm{z}$ continuum przestrzeni $\mathrm{w}$ taki sposób, aby po pierwsze dokonać jej degradacji, po drugie - wyłączyć z normalnego istnienia i spowodować jej przesłonięcie, zakrycie. Odgrodzić ją od reszty w najgłębszym tego słowa znaczeniu. [...] Szczelne zamknięcie getta stanowiło więc prolog do Zagłady nie tylko w sensie eksterminacji pośredniej, poprzez głód, choroby, represje. Było elementem strategii mentalnej eksterminacji świata za murami, tego, że ulatnia się on ze świadomości ludzi po drugiej stronie ${ }^{39}$.

Wiele wskazuje na to, że w Łodzi skuteczność tej strategii była szczególnie wysoka ${ }^{40}$.

36 Tamże, s. 143.

37 S. Selver-Urbach, Through the Window of my Home. Memories from Ghetto Lodz, Jerusalem 1986, s. 111-112. Cyt. za: Europa według Auschwitz, s. 221-222 (tłum. fragmentów włączonych do tej książki, S. Kelcz).

38 Zob. przypis 6. Zob. też T. Majewski, Ulice bez pamięci, w: Pamięć Shoah, s. 195-196.

39 J. Leociak, Topografia i egzystencja, s. 106.

40 T. Gierłowski (Europa wedtug Auschwitz, s. 219) przekonywał, co prawda, że „Polacy mieli 


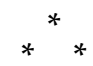

Dojmującą obecność przestrzeni w świadomości żydowskich autorów świadectw potwierdzają zatem - mimo tak nielicznych prób jej bezpośredniej prezentacji - te fragmenty prowadzonych przez nich zapisów, w których mowa jest o uwięzieniu, izolacji, granicznych płotach, tranzytowych ulicach czy bramach i mostach oddzielających od siebie poszczególne części getta. Najbardziej przenikliwi wcześnie odkryli, jak zawodne są analogie sytuacji, w jakiej się znaleźli, do tych praktyk segregacyjnych, którym Żydzi byli poddawani w przeszłości i - w konsekwencji - jak bardzo niewystarczające dla tej sytuacji okazały się dotychczasowe topologie zamknięcia. Potworny głód i wszechobecny terror sprzyjały rozpoznaniu tej przestrzeni jako „przedsionka Ostatecznego Rozwiązania" ${ }^{41}$. Bardzo często autorzy ci podkreślali również fakt, że to właśnie w jej ramach "czytają czas”. Jakub Poznański na przykład, który zaczął prowadzić dziennik 4 października 1941 r., pod tą datą zanotował: „Mamy obecnie trzeci rok wojny [...]. Jesteśmy uwięzieni w getcie łódzkim. Łódź zwie się teraz Litzmannstadt". Zapis z 2 maja 1943 r. otwiera taka oto uwaga: „Wczoraj upłynęło trzy lata, jak zamknięto getto, to znaczy jak nas, Żydów łódzkich, wtedy podobno koło 200000, odseparowano od reszty świata”. 30 sierpnia autor pisze: „Już kończą się cztery lata wojny [...]. Co przez ten normalnie dość krótki czas przeżyliśmy. Co świat widział? I co my, Żydzi z Łodzi, na swojej skórze odczuliśmy?". 1 grudnia tego roku dobitnie podkreśla szczególny ciężar gettowego doświadczenia: „Dziś rozpoczynamy 51 miesiąc wojny. A końca jeszcze nie widać. Ci [którzy] stoją na zewnątrz, pewnie nie mogą sobie wcale wyobrazić, jakie męki przechodzi ludność getta łódzkiego" ${ }^{42}$.

Przestrzeń tego getta ewokują też oczywiście - przywoływane w tekstach-świadectwach - nazwy ulic i placów czy adresy miejsc zamieszkania, pracy, punktów zaopatrzenia w żywność, siedzib władz itd. W okre-

świadomość tego, co się dzieje w getcie. Tego nie sposób było zatuszować. Getto było na to za duże, a ludzie zbyt ciekawi”, ale podkreślał przy tym, iż „starano się nie mówić o tym głośno. To była swego rodzaju tajemnica". Podczas wojny był jednakże małym chłopcem (urodził się w 1937 r.); być może zatem wiedzę tę uzyskał już po jej zakończeniu albo podzielił się ze swoją rozmówczynią późniejszymi przypuszczeniami. Znacząca pozostaje obserwacja o zachowaniu tajemnicy, o łączącym Polaków i łódzkich Niemców milczeniu na temat tego, co się widziało - milczeniu, dodajmy, trwającym dziesięciolecia.

41 Taką przestrzenną metaforę getta zaproponował J. Leociak (Topografia i egzystencja, s. 81). Autorzy tekstów powstałych w getcie nie znali oczywiście eufemistycznej formuły die Endlösung der Judenfrage. Wielu z nich miało jednak świadomość rzeczywistego celu nazistowskiej polityki wobec Żydów.

42 J. Poznański, Dziennik z łódzkiego getta, Warszawa 2002, s. [odpowiednio] 11, 62, 101, 135. 
ślonej przestrzeni odbywało się przymusowe wsiedlanie do getta $i$ „,wysiedlanie" $\mathrm{z}$ niego. $\mathrm{W}$ ten sposób jednak jest ona obecna $\mathrm{w}$ zapisach $\mathrm{z}$ wszystkich gett założonych przez okupantów na zagarniętych przez nich terytoriach, a nie tylko łódzkiego. $\mathrm{W}$ wielu $\mathrm{z}$ tych zapisów powtarza się obserwacja o stopniowym ubywaniu drzew, drewnianych bram, płotów, komórek, a nawet drzwi do "sławojek" - w gettach brakowało opału; ludzie zamarzali w lodowatych mieszkaniach. Każdy z uwięzionych mógłby z pewnością w tym, co o łódzkim powiedział Dawid Sierakowiak, rozpoznać miejsce, na które sam był skazany: „Chodzące trupy na naszych ulicach nadały już całemu gettu blady, stęchły, gruźliczy wygląd” ${ }^{43}$. Wszystkie okupacyjne "żydowskie dzielnice mieszkaniowe" mogą być też opisane przy pomocy "łańcucha metafor, które miały uchwycić fenomen getta" warszawskiego. Getto jako wyłaniająca się z nich ogólna metaforyczna formuła "dla topografii absurdu, obcości i zniewolenia; dla przestrzeni podzielonej, rozdartej i zranionej; dla egzystencji napiętnowanej, uwięzionej i udręczonej" ${ }^{44}$ określa ramy wszelkich prób uchwycenia swoistości obszaru w ten sposób naznaczonego.

Jako bodaj jedyne spośród innych gett, getto łódzkie stanowiło natomiast nie tylko - jak więzienia, szpitale psychiatryczne czy cmentarze - kontr-miejsce wykluczenia, ale też, będąc tym wszystkim zarazem, skupiało $\mathrm{w}$ sobie trudne do uzgodnienia właściwości wielu innych miejsc, spełniając tym samym warunki charakterystyczne dla (ironicznej) heterotopii. Ze względu na swą, uchodzącą za doskonałą, organizację i imponujące wyniki gospodarcze $^{45}$ getto to (w którym na powierzchni $4,13 \mathrm{~km}^{2}$ zamknięto już $\mathrm{w}$ pierwszych miesiącach jego istnienia 160000 ludzi) postrzegane było jak oddzielne przemysłowe miasto, „żydowskie centrum robotnicze Rzeszy” i „Żydowski

\footnotetext{
43 D. Sierakowiak, Dziennik, Warszawa 1960, s. 70.

44 J. Leociak, Topografia i egzystencja, s. 101.

45 Najdłuższe spośród innych gett przetrwanie i w konsekwencji ocalenie kilkunastu tysięcy więźniów, getto łódzkie zawdzięczało tyleż talentom organizacyjnym i bezwzględności Przełożonego Starszeństwa Żydów, M. C. Rumkowskiego i jego współpracowników po stronie żydowskiej, co bezprecedensowo silnej, samodzielnej pozycji Hansa Biebowa, jeszcze bardziej bezwzględnego cywilnego szefa niemieckiego Gettoverwaltung. Biebow zdobył tę pozycję za zasługi w przekształceniu getta we „wzorcowy” ośrodek pracy niewolniczej i utrzymał dzięki gigantycznym łapówkom. Profity czerpała zatem z niego nie tylko III Rzesza, ale też jego naczelny administrator i inni hitlerowscy dygnitarze. Pomysł, iż getto samo zarobi na swoje utrzymanie i przyniesie Niemcom wymierne korzyści, pochodził od Rumkowskiego, wiernego syjonistycznej idei „przewarstwowienia” - co w getcie sprowadzało się do maksymalnego zwiększenia liczby pracowników produkcji - stowarzyszonej z jego głębokim przekonaniem, iż dla Żydów jedynym ratunkiem jest wykazanie przydatności, czyli wyspecjalizowana praca wytwórcza.
} 
Okręg Przemysłowy" ${ }^{46}$; królestwo, żydowskie państwo ${ }^{47}$, miasto-państwo czy państewko z własnymi "ministerstwami”, bankiem i walutą ${ }^{48} \mathrm{z}$ jednej strony, z drugiej zaś jako koncentracyjny obóz pracy przymusowej - karykatura polis. Niemal całkowita izolacja Litzmannstadt Getto od tzw. strony aryjskiej to w pewnej mierze również konsekwencja tego ładu pozornej autonomii, zaprowadzonego przez Mordechaja Chaima Rumkowskiego, który traktował je (przynajmniej werbalnie) jak swoją własność ${ }^{49}$. Brak, tak charakterystycznych dla opowieści z innych gett, porównań między stronami żydowską i aryjską jest efektem owej izolacji - zadekretowanej przez władze okupacyjne, ale też z różnych względów pielęgnowanej przez żydowskie. Oto kolejna właściwość wyróżniająca getto łódzkie. Wydaje się zatem, że w jego przypadku to nie oś dzieląca przestrzeń na "tę" i "tamtą" stronę nadawała kształt doświadczeniu. $\mathrm{W}$ prowadzonych $\mathrm{w}$ getcie zapisach znaleźć można uwagi o sytuacji w getcie warszawskim i skrupulatnie odnotowywane wieści z odległych frontów, nie ma w nich jednak żadnych informacji o tym, co dzieje się w najbliższym sąsiedztwie.

Ponadto tylko Litzmannstadt Getto można opisać jako przestrzeń konfliktu nieznanego innym gettom. To tu przywiezionych zostało tysiące Żydów z Wiednia, Pragi, Luksemburga, Berlina i innych niemieckich miast i doszło do konfrontacji Ost Juden i Jekes ${ }^{50}$ : biednego, "niecywilizowanego" żydowskiego Wschodu i zamożnego, wykształconego, zasymilowanego, gardzącego ciemnym motłochem Zachodu. Nie istnieje chyba żaden związany $\mathrm{z}$ łódzkim gettem tekst, w którym nie byłoby mowy o owym konflikcie ${ }^{51}$.

46 D. Sierakowiak, Dziennik, s. 54, 71.

47 Zob. A. de Buton, Drobny przekrój getta, w: Kronika Getta Łódzkiego, t. 5., s. 203. „Ktokolwiek sądzi, że getto jest tylko gettem [...] sądzi fałszywie" - pisała w swoim felietonie - "getto w ogóle, w szczególności łódzkie, jest nader interesujące".

48 Kwity markowe (Markquittungen), zwane w getcie - od nazwiska lub imienia Przełożonego Starszeństwa Żydów - „rumkami” lub „chaimkami” zostały wprowadzone po to, by przejąć pieniądze, którymi dysponowała ludność getta. Ponieważ poza gettem „rumki” nie miały żadnej wartości, udaremniały ucieczki z getta (brak środków utrzymania) i poważnie utrudniały szmugiel. Zob. Pieniądze gettowe, w: Kronika, t. 5, s. 336.

49 „Przynależność do Prezesa, jego prawa własności podkreślane były wszędzie, we wszystkich oficjalnych napisach, na wszystkich szyldach: czy to szło o Uzdrowisko dla Dzieci Przełożonego czy to o sklep mięsa, towarów kolonialnych, sklepy rozdzielcze chleba, czy też o kuchnię nr 372 lub 2, sklep dietetyczny lub też Dom Sierot" - pisał B. Heilig (Pierwsze siedem miesięcy $w$ getcie Litzmannstadt, s. 209). Wyjaśniał jednak, że taka atrybucja była związana ze "skomplikowanym ustrojem kolektywnym", którego Rumkowski był reprezentantem.

50 W ten sposób nazywano co prawda w getcie przede wszystkim, budzących największą niechęć, Żydów niemieckich, ale rozciągano też to przezwisko na innych przybyszów z Zachodu. 51 Z problematyki Wschodu i Zachodu - eseje (w: Przemierzając szybkim krokiem getto...) to poświęcony mu cykl piętnastu tekstów autorstwa, przybyłego z Pragi dziennikarza i dramaturga, 
Oczywiście odróżniały to getto od innych kolejne - oprócz trzech mostów, pamiętnych też ze względu na samobójstwa tam popełniane - bardzo silnie nacechowane, "newralgiczne" miejsca. Takim nacechowaniem odznaczało się niemal całe Stare Miasto i Bałuty ze swą złą przedwojenną sławą, "mieszanina nędzy i przestępstwa" 52, a na Bałutach - Bałucki Rynek (terytorium o dziwnym statusie, gdzie można było wejść tylko za okazaniem specjalnej przepustki) z kamienicą na Łagiewnickiej 25, na której został umieszczony zegar wzorcowy, wskazujący obowiązujący w getcie czas; położony na tej samej ulicy wielki szpital i Centralne Więzienie na Czarnieckiego. Na Placu Kościelnym mieściły się: górujący nad gettową częścią Bałut kościół pod wezwaniem Wniebowzięcia Najświętszej Marii Panny zwany „białą fabryką"53; "Rote Haus", czyli siedziba Kripo w dawnym domu parafialnym (Kościelna/Kirchgasse 7/8); siedziba redakcji archiwum getta w narożnej kamienicy u zbiegu Zgierskiej i Brzezińskiej (dziś Wojska Polskiego). Dla więźniów getta ważne były też rozrzucone $\mathrm{w}$ różnych jego częściach siedziby poszczególnych resortów oraz place - „strażacki”, ,bazarowy”, "rybny” czy "węglowy". Niektóre z tych miejsc zyskały trafne charakterystyki funkcjonalne. Do częstego w przemówieniach Der Aelteste przedstawiania getta jako żywego organizmu nawiązał prawdopodobnie Oskar Singer, nazywając Bałucki Rynek - „brudny plac w najbrudniejszej Łodzi” i miejsce, z którego Rumkowski sprawował swoją iluzoryczną władzę - „sercem i mózgiem getta", Matrosengasse (Dworską) zaś jego "tętnicą", ponieważ na tej ulicy znajdowały się ważne resorty administracyjne, i zarazem „brzuchem”, bo mieścił się tam również Wydział Zaopatrzenia, Transportu i biura Centrali Mleczarskiej ${ }^{54}$.

Tylko w przestrzeni getta łódzkiego możliwe było, z racji jego ukształtowania i zabudowy, wydzielenie dwu stref: administracyjno-przemysłowo-mieszkaniowej i letniskowo-wypoczynkowej, zwanej w getcie Szyszkowicami ${ }^{55}$. Teren tej drugiej to przed wojną zamieszkały głównie przez Polaków Marysin - z różnych powodów wytęskniony, uprzywilejowany, zdecydowanie różny od pozostałej, miejskiej części getta i zarazem budzący lęk.

Oskara Singera. Sporo uwagi poświęcił temu konfliktowi A. Mostowicz (Żółta gwiazda i czerwony krzyż, s. 42-53. Zob. też dokumentalne filmy: Radegast (reż. B. Lankosz, scen. A. Bart, 2008), Bałuckie getto (reż. i scen. Pavel Štigl, 2008) i Litzmannstadt Getto. Piekło na ziemi obiecanej (reż. i scen. M. Olbrychowski, 2009).

52 A. Mostowicz, Żółta gwiazda i czerwony krzyż, s. 85.

53 Nazywany tak od koloru puchu i pierza, których sortownię umieszczono w jego wnętrzu w $1943 \mathrm{r}$.

54 O. Singer, Przemierzajac szybkim krokiem getto..., s. 74.

55 Zob. J. Poznański, Dziennik z łódzkiego getta, s. 99. 
Marysin bowiem to nie tylko pola i małe drewniane domki z ogródkami, służące m.in. za letnie „rezydencje” gettowych sziszkies (szyszek), gettowe „plantacje”, Heimy (domy wypoczynkowe), sierocińce, kolonie i półkolonie dla dzieci, ale też rozciągający się u jego wschodnich granic ogromny cmentarz z tzw. polem gettowym, na którym w latach 1940-1944 pochowano kilkadziesiąt tysięcy osób zmarłych z głodu, chorób, wycieńczającej pracy ${ }^{56}$. Przez Marysin prowadziła też droga do "łódzkiego Umschlagplatz" - usytuowanej poza terenem getta stacji Radegast, z której odchodziły transporty do obozów zagłady.

Jednakże - powtórzę - niemal wszystko, co tu wymieniłam, oprócz problematyki konfliktu między Żydami wschodnimi i zachodnimi, jest w Kronice, dziennikach, pamiętnikach czy felietonach z tego getta dojmująco obecne, nazywane, ale $\mathrm{w}$ zasadzie nieprzedstawione. Przedmiotem przedstawienia stanie się dopiero $\mathrm{w}$ tak nisko przez niektórych cenionych powieściach $\mathrm{i}$ innych prototypowych formach literackich. To w nich odnaleźć można takie próby topografii Litzmannstadt Getto lub jego wybranych fragmentów, które pozwalają na wyobrażeniową wizualizację i w konsekwencji - skonkretyzowaną lokalizację doświadczenia protagonistów. Wszelako niektóre powieściowe konstrukcje tej przestrzeni czy usytuowanych w jej ramach swoistych dla niej obiektów sprawiają, że w wątpliwość podać można nie tylko - oparte na mocnych, wydawałoby się przesłankach - domniemania, ale też autorskie deklaracje o getcie łódzkim jako miejscu akcji.

\section{Experienced Space, Created Space: Literary Topographies of Litzmannstadt Getto (Reconnaissance). Part One}

\section{Summary}

In this part of the article I discuss the question of potential relations between the styles of the topography of Litzmannstadt Getto and the situation of the authors of non-fictional and fictional texts devoted to it. I distinguish, for example, records of the space of this ghetto made by

\footnotetext{
56 O dojmującej i nieprzypadkowej bliskości tego miejsca wiecznego spoczynku i gettowego wypoczynku opowiada w piosence A 'pensjonat' (albo Pola Marysina), uliczny pieśniarz Litzmannstadt Getto, Jankiel Herszkowicz. Zob. film Elada Dana i Yosi Godarda, The King and the Jester: a Soul Song to Ghetto Lodz (Izrael, 1999). „Wiza na Marysin” z innej piosenki Herszkowicza - o Jeke mit e teke ( $z$ teczka lub walizką) krążącym po getcie, w którym już od dawna „nie ma co kupić", w poszukiwaniu pożywienia - oznacza, że jedynym efektem tych poszukiwań będzie grób na marysińskim cmentarzu.
} 
those who experienced it (endotopia) as well as those whose creators modeled it from an external perspective: culturally, discursively mediated (exotopia). I state that in non-fictional narrations-testimonies space is ubiquitous, foremost as the figure of closing and enslavement, though basically unrepresented. For only in but a few of them one can find topographies of the Lodz Ghetto understood as involving senses, conducive to visualizations, imaginary reconstruction: descriptions of the organization of this space, its appearance and endemic properties.

Keywords: space, literary topography, experience, creation, Litzmannstadt Getto 